\title{
Impact of different earthworm ecotypes on water stable aggregates and soil water holding capacity
}

\author{
Jamal Hallam ${ }^{1,2}$ (D) Mark E. Hodson ${ }^{1}$ \\ Received: 20 June 2019 /Revised: 3 January 2020 / Accepted: 9 January 2020 /Published online: 1 February 2020 \\ (C) The Author(s) 2020
}

\begin{abstract}
We carried out mesocosm experiments using either the anecic earthworm Lumbricus terrestris or the endogeic earthworm Allolobophora chlorotica and loam, silt loam and sandy loam soils to investigate the differing impact of these earthworm of different ecotypes on aggregate formation (percentage water stable aggregates, \%WSA) and soil water holding capacity (WHC), two soil properties that underpin many of the ecosystem services provided by soils. Earthworms significantly increased \%WSA (by 16-56\% and 19-63\% relative to earthworm-free controls for L. terrestris and A. chlorotica, respectively). For L. terrestris, this increase was significantly greater in the upper $6.5 \mathrm{~cm}$ of the soil where their casts were more obviously present. Allobophora chlorotica treatments significantly increased WHC by $7-16 \%$. L. terrestris only caused a significant increase in WHC (of $11 \%$ ) in the upper $6.5 \mathrm{~cm}$ of the sandy loam soil. Linear regression indicated a consistent relationship between increases in \%WSA and WHC for both earthworm species. However, for a given \%WSA, WHC was higher for A. chlorotica than L. terrestris likely due to the known differences in their burrow structure. Overall, earthworms increased soil \%WSA and WHC but the significant species/ecotype differences need to be considered in discussions of the beneficial impacts of earthworms to soil properties.
\end{abstract}

Keywords Earthworms $\cdot$ Lumbricus terrestris $\cdot$ Allolobophora chlorotica $\cdot$ Water stable aggregates $\cdot$ Water holding capacity

\section{Introduction}

The development of sustainable agricultural management systems that deliver a range of ecosystem services would benefit from a full understanding of the impacts of soil fauna on soil properties. Soil macrofauna use the soil as a habitat and a source of food, and consequently, they exert a large influence on the physical properties of soils through the diversity and

Electronic supplementary material The online version of this article (https://doi.org/10.1007/s00374-020-01432-5) contains supplementary material, which is available to authorized users.

Jamal Hallam

jamal.hallam@gmail.com

Mark E. Hodson

mark.hodson@york.ac.uk

1 Department of Environment and Geography, University of York, Wentworth Way, Heslington, York YO10 5NG, UK

2 National Institute of Agricultural Research of Morocco, Avenue des FAR, B.P. 124, Inezgane, Agadir, Morocco abundance of the structures they produce (Boivin and KohlerMilleret 2011). Earthworms change the soil structure by modifying soil aggregation and porosity (Shipitalo and Le Bayon 2004; Blouin et al. 2013; Hallam et al. 2020). Aggregates and the space between them allow the retention and exchange of both air and water (Guber et al. 2004; Saha and Kukal 2015) and thus affect water flow and retention and soil aeration (Bastardie et al. 2003; Capowiez et al. 2014, 2015; Hallam et al. 2020; Lavelle et al. 1992). Additionally, soil aggregates contain the majority of organic carbon in soil and contribute to nutrient release for plant growth (Cornforth 1968; Ramachandran Nair et al. 2010). These changes in turn affect the ecosystem services provided by soils such as being a medium for plant growth and providing storage and filtration of water (Edwards 2004; Hallam et al. 2020; Li et al. 2013; Zhang et al. 2016). Soil water holding capacity (WHC) is one measure of water retention and is an important soil parameter for monitoring soil function and processes (Hong et al. 2013; Rousseva et al. 2017). It is a function of a variety of soil properties including texture, organic matter content and soil aggregation (Hudson 1994; Saxton et al. 1986); is easily measurable; and is a key factor in soil ecology as it influences the distribution and dynamics of animal and plant populations (BIO Intelligence Service and Communities 2014). 
Earthworms are major ecosystem engineers in the soil and influence soil structure by creating macropores through their burrowing activities; they play an important role in aggregate formation and stabilization through the ingestion and egestion of soil (Blouin et al. 2013; Bottinelli et al. 2015; Guild 1955; Lee and Foster 1991; Six et al. 2002; Snyder et al. 2009). Earthworms can be grouped into three ecological groups (Bouché 1977): Epigeic earthworms (e.g. Lumbricus rubellus) are litter dwellers that consume plant residue on the soil surface and rarely ingest mineral soil; endogeic earthworms (e.g. Allolobophora chlorotica) are geophagous and inhabit the upper layers of the soil, construct narrow branching sinuous burrows and rarely come out to the soil surface; and anecic earthworms (e.g. Lumbricus terrestris) are deep vertical burrowers that typically inhabit semipermanent deep burrows and feed on organic litter which they collect from the soil surface.

Early studies established the role of earthworms in aggregate formation. Hopp and Hopkins (1946) found that L. terrestris increased the amount of water stable aggregates in sieved soil relative to earthworm-free controls. Swaby (1950) proposed that such increases were related to increased microbial activity in the earthworm gut, in turn related to levels of organic matter in the ingested soil, leading to an increased level of "bacterial gum" binding aggregates together. Guild (1955) suggested that the impact of earthworms on soil aggregation was related to the way different earthworm species process the soil and the proportions of different species and their numbers within the soil. In experiments, he found that, relative to unworked soil that was practically structureless, all earthworm species increased aggregation; epigeic species had the least effect and anecic species the greatest. Since then, investigations have continued to refine our understanding of the interaction of earthworms and other factors such as soil type, land management practices, fungal mycelium and organic matter content as it relates to aggregate production. Studies with epigeic earthworms typically find little effect on soil aggregation compared with other earthworm ecotypes because the earthworms rarely burrow within the soil (Bossuyt et al. 2006; Guild 1955; Shipitalo and Le Bayon 2004). However, contrasting results are found for anecic and endogeic earthworms with most studies recording increases in percentage water stable aggregates (\%WSA) (e.g. Buck et al. (2000), Flegel et al. (1998), Hamilton et al. (1988), Ketterings et al. (1997) and Shipitalo and Protz (1989) for the anecic L. terrestris and Blanchart (1992), Bossuyt et al. (2005), Buck et al. (2000) and Haynes and Fraser (1998) for the endogeic A. caliginosa, Millsonia anomala, and Octolasion cyaneum) due to the increased processing of organic matter, increases in microbial activity and increased abundance of fungal hyphae in the presence of earthworms together with age-hardening and age-drying processes of earthworm casts forming new bonds between soil particles. A few studies report either no effect or a decrease in \%WSA following earthworm-processing of soil (e.g. the anecic L. terrestris, Aporrectodea longa and Aporrectodea giardi and the endogeic A. caliginosa) (Jégou et al. 2001; Schrader and Zhang 1997; Shuster et al. 2000; Zhang and Schrader 1993). Whilst not discussed in the original studies, possible explanations for this include earthworm ingestion leading to the dispersion of clay particles, there being insufficient organic $\mathrm{C}$ to increase the $\mathrm{C}$ content of aggregates despite earthwormprocessing or simply experiment duration being insufficient for casts to harden and stabilize. Further studies record differences in effect depending on other properties. For example, Blanchart et al. (1997) recorded decreases in $\%$ WSA at a soil depth of $0-5 \mathrm{~cm}$, but increases in $\% \mathrm{WSA}$ at 10-15 cm for the endogeic earthworms M. anomala, Chuniodrilus zielae, and Stuhlmannia porifera though legacy effects of old earthworm casts in the soil caused them to question their results.

Whilst there are many studies that find that earthworms increase the amounts of water stable aggregates in soil, there are relatively few studies on the impacts of earthworms on soil WHC (Edwards 2004). The majority of studies consider the impact of soil water content and soil WHC on earthworm distributions rather than the other way around (Palm et al. 2013; Schneider and Schroder 2012;). The few studies that exist are superficially contradictory, but this is most likely because they measure different things. Guild (1955) and Stockdill and Cossens (1969) reported an increase in WHC after $A$. caliginosa, L. terrestris and A. longa processing of soil but Ernst et al. (2009) observed a decrease in soil water storage in laboratory experiments using L. terrestris or A. caliginosa species due to increased evaporation because of the pores created by the earthworms increasing soil aeration. Guild (1955) did not detect an increase in WHC in the presence of the epigeics L. rubellus and D. subrubicunda, attributing this to them not producing significant amounts of water holding aggregates but both Smagin and Prusak (2008) and Ernst et al. (2009) reported an increase in WHC in the casts of epigeic earthworms from laboratory experiments. In field experiments with kaolinitic soils and tropical earthworms, Blanchart et al. (1999) found that compacting endogeic species (Pontoscolex corethrurus or M. anomala) increased WHC whereas decompacting endogeic species (eudrilid earthworms) decreased WHC. However, Blouin et al. (2007) observed a decrease in WHC in laboratory experiments using a sandy soil in the presence of M. anomala, demonstrating the complex interaction between earthworm type, soil properties and the influence that earthworms have on those properties.

Although many studies have investigated the impacts of earthworms on soil aggregation, and some have investigated the impacts of earthworms on WHC, relatively few investigate the relationship between these two properties (Blanchart et al. 1999; Guild 1955); such studies are vital to fully understand 
earthworm drivers of soil properties and the ecosystem services they provide. To address this gap, we investigated the impact of two common globally distributed earthworm species on \%WSA and soil WHC. Our experiments contrast the influence of the anecic earthworm L. terrestris and the endogeic earthworm A. chlorotica on both aggregate formation and soil water holding capacity. Our use of two different ecotypes in a consistent experimental design allows the evaluation of the potentially differing impacts these ecotypes have on the delivery of ecosystem services. We measured the $\% \mathrm{WSA}$ and WHC in the upper and lower portions of the soil in order to investigate the spatial variation of changes in these properties due to earthworm activity. Like many earthworm experiments, in order to detect effects in the course of a relatively short time period experiment (40 days), we used higher earthworm abundances than would be encountered under field conditions and constrained earthworms to a fixed volume of soil. Further, we did not add a food source to the soil to encourage the earthworms to process the soil. The earthworms were added to loam, silt loam and sandy loam soils. We hypothesised that (i) the horizontally burrowing, soil-feeding A. chlorotica will have more of an effect on the measured soil properties than surface-feeding, vertical-burrowing L. terrestris; (ii) both earthworms species will increase water holding capacity because of changed soil structure, (iii) the least effects will occur in soils with higher organic matter contents due to the significant role that organic matter plays in controlling soil properties regardless of earthworm activity; and (iv) effects will be more marked in soils with finer textures due to the role that clay particles play in aggregation.

\section{Materials and methods}

\section{Soils and earthworm selection and mesocosm establishment}

Soil was collected from the top $20 \mathrm{~cm}$ from three fields (Big Substation East, Valley and Copse) at the University of Leeds commercial farm $\left(53^{\circ} 51^{\prime} 44^{\prime \prime} \mathrm{N}, 1^{\circ} 20^{\prime} 35^{\prime \prime} \mathrm{W}\right)$. The soils are Cambisols (WRB 2006) and have different textures. Each soil was air-dried, sieved at $2 \mathrm{~mm}$ and thoroughly homogenized to remove any legacy effects of previous earthworm activity.
Basic soil properties and land management information are presented in Table 1. $\mathrm{pH}$ was determined on 1:2.5 soil:water mixtures (Ministry of Agriculture Fisheries and Food 1986) using an Orion 420Aplus pH meter (Thermo Orion, USA), soil organic matter content by loss on ignition at $350{ }^{\circ} \mathrm{C}$ (Ayub and Boyd 1994; CEAE 2003), field dry bulk density using soil density rings of $95 \mathrm{~cm}^{3}$ volume and soil texture using a MasterSizer2000 laser particle size analyser (Malvern Instruments, UK). A standard sand $\left(\mathrm{SiO}_{2}, \mathrm{CAS}\right.$ 14808-60-7) was used as an in house reference material for the particle size analyser which reported the mean grain size distribution at the 10th, 50th and 90th percentile to within $1 \%$ percent.

For each soil, $300 \mathrm{~g}$ of air-dried soil was wetted with deionized water up to a gravimetric water content of $30 \%$ to sustain earthworm activity (Berry and Jordan 2001; Butt and Lowe 2011; Lowe and Butt 2005). The moist soil was put in sealed laboratory bags punctured with pin holes, to prevent earthworms from escaping but to allow the exchange of air. The soil bags were placed in plastic beakers to support the soil and to give irregularly shaped columns of soil of approximately $6 \mathrm{~cm}$ diameter and $13 \mathrm{~cm}$ height and an approximate density of $0.82-1.00 \mathrm{~g} \mathrm{~cm}^{-3}$. The irregular shape of the soil columns prevents a more accurate calculation. The soil was then stored at $15{ }^{\circ} \mathrm{C}$ until the addition of earthworms. Lumbricus terrestris can produce burrows of several metres depth (Edwards and Bohlen 1996) which is clearly not possible in our relatively short soil columns. However, L. terrestris is also found in shallow soils, and in short soil column experiments such as these are still observed to process the soil to produce vertical burrows in which it rests.

Clitellate, adult earthworms of the vertical burrowing, anecic, Lumbricus terrestris and the green morph of the horizontal burrowing, endogeic, Allolobophora chlorotica species were used in this experiment. L. terrestris were purchased from Blades Biological Ltd. (Edenbridge, UK), and A. chlorotica were collected from the same fields as the test soils and identified using the OPAL earthworm identification key (Jones and Lowe 2009). The earthworms were rinsed with deionized water and acclimatized in containers containing the test soils at $15{ }^{\circ} \mathrm{C}$ in darkness. After 3 days, the viable adult earthworms were rinsed again with deionized water, dried with tissue paper weighed and added to the mesocosms to give

Table 1 Physical and chemical properties of soils selected for the experiment (mean \pm standard deviation, $n=3$ apart from for field dry bulk density measurements where $n=2$ and both measurements are given)

\begin{tabular}{|c|c|c|c|c|c|c|c|c|}
\hline Field name & Land use & $\mathrm{pH}$ & Organic matter $(\%)$ & $\begin{array}{l}\text { Field dry bulk } \\
\text { density }\left(\mathrm{g} \mathrm{cm}^{-3}\right)\end{array}$ & $\begin{array}{l}\text { Clay }(\%) \\
<2 \mu \mathrm{m}\end{array}$ & $\begin{array}{l}\text { Silt (\%) } \\
2-50 \mu \mathrm{m}\end{array}$ & $\begin{array}{l}\text { Sand }(\%) \\
50-2000 \mu \mathrm{m}\end{array}$ & Texture \\
\hline Copse & Arable & $7.71 \pm 0.10$ & $3.41 \pm 0.19$ & $1.56,1.54$ & $8.44 \pm 0.44$ & $43.65 \pm 2.02$ & $47.92 \pm 2.46$ & Loam (L) \\
\hline Big Substation East & Arable & $7.64 \pm 0.11$ & $3.60 \pm 0.22$ & $1.38,1.51$ & $4.32 \pm 0.13$ & $52.12 \pm 1.49$ & $43.56 \pm 1.61$ & Silt loam (SiL) \\
\hline Valley & Pasture & $7.27 \pm 0.05$ & $9.59 \pm 0.02$ & $1.22,1.14$ & $3.08 \pm 0.54$ & $41.57 \pm 6.08$ & $55.35 \pm 6.60$ & Sandy loam (SaL) \\
\hline
\end{tabular}


either 2 L. terrestris $(9.04 \pm 0.52 \mathrm{~g})$ or 8 A. chlorotica $(2.16 \pm$ $0.11 \mathrm{~g}$ ) per mesocosm ( $n=12$ per species). Considered on a mass of earthworm per mass of soil basis, these abundances are far higher than those encountered in the field (Holden et al. 2019). We used these high densities in our experiments to compensate for the relatively short time scale (40 days) of our experiments, in order to be able to detect effects. The mesocosms (4 replicates of control and earthworm-present treatments for each of the three soil textures for each species) were maintained in a controlled environment room $\left(15 \pm 1{ }^{\circ} \mathrm{C}\right.$ and $60 \pm 7 \%$ rh) in the dark (Lowe and Butt 2005) for 40 days. They were weighed initially and then every week with any mass loss being corrected by addition of deionized water to maintain a constant soil moisture content. At the end of the experiment, earthworms were removed, rinsed with deionized water, dried with tissue paper and weighed. The soil was divided into "upper soil" (0-6.5 cm) and "lower soil" (6.5$13 \mathrm{~cm})$. Soil from the individual layers was homogenized by gentle mixing. Multiple subsamples of damp material (< $0.5 \mathrm{~g}$ ) were taken to give sufficient mass for WHC measurement. The rest of the soil was then air-dried, and multiple subsamples were again taken to give sufficient mass for $\%$ WSA measurement.

\section{Soil physical properties measurement}

The percentage water stable aggregates (\%WSA) and water holding capacity (WHC) of the soils were measured at the start and end of the experiment.

The \%WSA was measured using bespoke wet sieving equipment (Wet Sieving Apparatus; Eijkelkamp soil and water Agrisearch Equipment Art no. 08.13) with a 250- $\mu$ m sieve size on $4 \mathrm{~g}$ of air-dried soil that was previously sieved to 1$2 \mathrm{~mm}$. Unstable aggregates were broken up and collected by raising and lowering the soil sample into water at a rate of 34 times per minute for a period of $3 \mathrm{~min}$. Material $<250 \mu \mathrm{m}$ passed through the sieve and was collected, oven dried at $105{ }^{\circ} \mathrm{C}$ and weighed. A dispersing solution of sodium hexametaphosphate was then added, and the process repeated to break up and collect the water stable aggregates, leaving primary particles $>250 \mu \mathrm{m}$ behind. The $\%$ WSA was calculated, after correction for the mass of sand $>250 \mu \mathrm{m}$, as the weight of water stable aggregates divided by the total weight of aggregates (Kodešová et al. 2009; Milleret et al. 2009a).

WHC was determined following the method of ISO 11274 (2019). In brief, c. 50 g (oven dried equivalent weight) of damp soil was placed into open tubes of $3.5 \mathrm{~cm}$ diameter and $5 \mathrm{~cm}$ length with mesh bases. The filled tubes were placed in a container of water and allowed to wet up by capillary action. When the soil surfaces had a glossy appearance, the cores were removed from the water and allowed to drain until they stopped dripping. The soil in the cores was then gently removed and weighed. The water holding capacity of the cores was determined as the weight of water held in the soil cores compared with the $105^{\circ} \mathrm{C}$ oven dry weight of the sample.

\section{Statistical analysis}

The change in mass of the earthworms between the start and end of the experiment was analysed separately for $L$. terrestris and $A$. chlorotica, using one-way analysis of variance (ANOVA) with change in mass as a proportion of the original mass as the factor and Bonferroni post hoc pairwise comparisons. As it was impossible to identify individual earthworms, analysis was carried out on total earthworm mass per replicate. Initial values of \%WSA and \%WHC were compared between soils using one-way ANOVA and Bonferroni post hoc pairwise comparisons. The L. terrestris and A. chlorotica experiments were run at different times, generating two control groups of data. For ease of interpretation, the post experiment $\% \mathrm{WSA}$ and $\% \mathrm{WHC}$ data sets for each species were therefore analysed separately using a three-way analysis of variance (ANOVA) with repeated measures. Factors were soil texture, earthworm absence/presence and upper/lower soil layer with the upper/lower soil layer representing the repeated measure. The relative changes in \%WSA and WHC due to the presence of earthworms were analysed using a two-way ANOVA with repeated measures with soil texture and upper/lower soil layer as factors with the upper/lower soil layer representing the repeated measure. All computations were made using SPSS (IBM Corp. Released 2016, version 24) with differences between different combinations of factors in the repeated measures analyses being compared using contrasts (Field 2009). Summary ANOVA tables are presented in the Supplementary Information. We assessed relationships between \%WSA and soil WHC for L. terrestris and A. chlorotica using linear regression. Differences in the slopes and intercepts of the regression lines were tested for their significance between species using GraphPad Prism (GraphPad, Inc. Released on November 2017, version 7. 04).

\section{Results}

All the earthworms were recovered at the end of the experiments. The mean mass of $L$. terrestris earthworms decreased significantly over the course of the experiment in all three soils whereas the mass of the $A$. chlorotica only decreased in the loam (L) and silt loam (SiL) soils $(p \leq 0.05)$ (Table 2$)$. Mass loss was less than the critical limit of $30 \%$ suggested to ensure the validity of laboratory experimental results (Frund et al. 2010).

Table 3 (L. terrestris) and Table 4 (A. chlorotica) show the $\%$ WSA at the beginning and end of the experiments. Before the experiment began and at the end of the experiment, the sandy loam (SaL) showed a significantly greater \%WSA than 
Table 2 Mean total $L$. terrestris and A. chlorotica mass (g) at the start and end of the experiment and percentage mass loss $(n=4$ replicates, \pm standard deviations)

\begin{tabular}{lllll}
\hline $\begin{array}{l}\text { Earthworm } \\
\text { species }\end{array}$ & $\begin{array}{l}\text { Soil } \\
\text { texture }\end{array}$ & $\begin{array}{l}\text { Initial total earthworm } \\
\text { mass }(\mathrm{g})\end{array}$ & $\begin{array}{l}\text { Final total earthworm } \\
\text { mass }(\mathrm{g})\end{array}$ & $\begin{array}{l}\text { Average percentage } \\
\text { mass loss }\end{array}$ \\
\hline L. terrestris & Loam* & $8.88 \pm 0.41$ & $6.60 \pm 0.39$ & $25.57 \pm 4.43 \%$ \\
& $\begin{array}{l}\text { Silt loam* } \\
9.18 \pm 0.71\end{array}$ & $7.30 \pm 0.81$ & $20.34 \pm 7.95 \%$ \\
& $\begin{array}{l}\text { Sandy } \\
\text { loam* }\end{array}$ & $9.08 \pm 0.61$ & $7.76 \pm 0.78$ & $14.37 \pm 8.25 \%$ \\
& Loam* & $2.15 \pm 0.05$ & $1.56 \pm 0.10$ & $27.16 \pm 6.42 \%$ \\
& Silt loam* & $2.20 \pm 0.10$ & $1.74 \pm 0.09$ & $21.04 \pm 4.01 \%$ \\
& $\begin{array}{c}\text { Sandy } \\
\text { loam }\end{array}$ & $2.16 \pm 0.15$ & $2.11 \pm 0.13$ & $1.60 \pm 12.48 \%$ \\
& & & \\
\hline
\end{tabular}

*The mean difference between the initial and final mass for the given soil texture is significant at the 0.05 level the other two soils $(p<0.001)$. The addition of both earthworm species increased significantly the \%WSA in the upper and lower soils compared with the control $(p<0.001)$. There was no significant difference between the upper and lower soils for A. chlorotica but \%WSA was greater in the upper than the lower soils in the L. terrestris experiments $(p \leq 0.05)$. For $L$. terrestris, there was a significant interaction between the soil texture and the presence/absence of earthworms with the increase in \%WSA in the presence of earthworms being significantly greater in the $\mathrm{L}$ than the $\mathrm{SiL}$ and SaL soils. For both $L$. terrestris and A. chlorotica, there was no significant difference in the relative increase in \%WSA between the lower and upper layers but the relative increases were greatest for the $\mathrm{L}$ and least for the SaL soils $(p \leq 0.05)$.

WHC of the soils at the start and end of the experiments is shown in Table 3 (L. terrestris) and Table 4 (A. chlorotica). Before the experiment began and at the end of the experiment, the SaL soil had the highest, and the L soil the lowest, WHC $(p<0.001)$. The presence of $L$. terrestris caused a marginal increase in WHC $(p=0.06)$ with the increase in WHC being almost significantly greater in $\mathrm{SaL}$ relative to the $\mathrm{SiL}$ soil $(p=$ 0.06). In contrast to L. terrestris, A. chlorotica significantly increased WHC $(p<0.001)$ with this increase being greater in

Table 3 Mean percentage of water stable aggregates (\%WSA) and water holding capacity (WHC) of upper soils and lower soils in the presence (soil + earthworms) and absence (control) of L. terrestris within each soil texture. Initial soil is the soil at the start of the experiment. Data from the upper than the lower soil layers $(p<0.05)$. In contrast to $\%$ WSA, there were no significant differences in the relative increase of WHC between soils.

For each experiment, there was a statistically significant strong (i.e. $p<0.0001, r>0.5$, Cohen 1988) positive relationship between the \%WSA and soil WHC (Fig. 1). Although the strength of the correlations is greater for the A. chlorotica than L. terrestris experiments, the slopes of the linear regressions are not significantly different between species. However, the intercepts of the linear regressions are significantly larger $(p<0.0001)$ for A. chlorotica .

\section{Discussion}

\section{Earthworm biomass}

In our experiments, we deliberately did not feed the earthworms in order to encourage them to intensely process the soil (Abbott and Parker 1981). In almost all the treatments, the earthworms lost weight (Table 2), though weight loss was within the acceptable range for laboratory experiments (Frund et al. 2010). The decrease in mass of the anecic L. terrestris is

the same row of the same soil texture and soil depth with different superscripts are significantly different $(p<0.05)$. $(n=4$ replicates, \pm standard deviations)

\begin{tabular}{|c|c|c|c|c|c|c|c|}
\hline \multirow[t]{2}{*}{ Soil texture } & \multirow[t]{2}{*}{ Measured soil depth } & \multicolumn{3}{|l|}{$\%$ WSA } & \multicolumn{3}{|l|}{ WHC $\left(\mathrm{g} \mathrm{g}^{-1}\right)$} \\
\hline & & Initial soil & Control & Soil + earthworms & Initial soil & Control & Soil + earthworms \\
\hline \multirow[t]{2}{*}{ Loam } & Upper soils & $51.49 \pm 5.84^{\mathrm{a}}$ & $45.91 \pm 6.73^{\mathrm{a}}$ & $71.65 \pm 3.47^{\mathrm{b}}$ & $0.30 \pm 0.009^{\mathrm{a}}$ & $0.30 \pm 0.004^{\mathrm{a}}$ & $0.33 \pm 0.056^{\mathrm{a}}$ \\
\hline & Lower soils & $51.49 \pm 5.84^{\mathrm{a}}$ & $42.94 \pm 2.80^{\mathrm{a}}$ & $64.68 \pm 6.01^{\mathrm{b}}$ & $0.30 \pm 0.009^{\mathrm{a}}$ & $0.30 \pm 0.014^{\mathrm{a}}$ & $0.30 \pm 0.007^{\mathrm{a}}$ \\
\hline \multirow[t]{2}{*}{ Silt loam } & Upper soils & $52.04 \pm 3.78^{\mathrm{a}}$ & $50.31 \pm 5.44^{\mathrm{a}}$ & $68.30 \pm 2.34^{\mathrm{b}}$ & $0.35 \pm 0.007^{\mathrm{a}}$ & $0.33 \pm 0.008^{\mathrm{a}}$ & $0.35 \pm 0.017^{\mathrm{a}}$ \\
\hline & Lower soils & $52.04 \pm 3.78^{\mathrm{ab}}$ & $48.07 \pm 6.40^{\mathrm{a}}$ & $61.99 \pm 3.49^{\mathrm{b}}$ & $0.35 \pm 0.007^{\mathrm{a}}$ & $0.34 \pm 0.021^{\mathrm{a}}$ & $0.34 \pm 0.013^{\mathrm{a}}$ \\
\hline \multirow[t]{2}{*}{ Sandy loam } & Upper soils & $75.96 \pm 3.78^{\mathrm{b}}$ & $63.36 \pm 3.45^{\mathrm{a}}$ & $82.99 \pm 1.12^{\mathrm{c}}$ & $0.39 \pm 0.010^{\mathrm{a}}$ & $0.39 \pm 0.010^{\mathrm{a}}$ & $0.44 \pm 0.020^{\mathrm{b}}$ \\
\hline & Lower soils & $75.96 \pm 3.78^{\mathrm{b}}$ & $65.11 \pm 4.32^{\mathrm{a}}$ & $75.27 \pm 4.93^{\mathrm{b}}$ & $0.39 \pm 0.010^{\mathrm{a}}$ & $0.39 \pm 0.029^{\mathrm{a}}$ & $0.40 \pm 0.017^{\mathrm{a}}$ \\
\hline
\end{tabular}


Table 4 Mean percentage of water stable aggregates (\%WSA) and water holding capacity (WHC) of upper soils and lower soils in the presence (soil + earthworms) and absence (control) of A. chlorotica within each soil texture. Initial soil is the soil at the start of the experiment. Data from the same row of the same soil texture and soil depth with different superscripts are significantly different $(p<0.05)$. ( $n=4$ replicates, \pm standard deviations)

\begin{tabular}{|c|c|c|c|c|c|c|c|}
\hline \multirow[t]{2}{*}{ Soil texture } & \multirow[t]{2}{*}{ Measured soil depth } & \multicolumn{3}{|l|}{$\% \mathrm{WSA}$} & \multicolumn{3}{|l|}{ WHC $\left(\mathrm{g} \mathrm{g}^{-1}\right)$} \\
\hline & & Initial soil & Control & Soil + earthworms & Initial soil & Control & Soil + earthworms \\
\hline \multirow[t]{2}{*}{ Loam } & Upper soils & $51.49 \pm 5.84^{\mathrm{a}}$ & $41.30 \pm 8.25^{\mathrm{a}}$ & $67.52 \pm 3.90^{\mathrm{b}}$ & $0.30 \pm 0.009^{\mathrm{a}}$ & $0.31 \pm 0.004^{\mathrm{a}}$ & $0.34 \pm 0.020^{\mathrm{b}}$ \\
\hline & Lower soils & $51.49 \pm 5.84^{\mathrm{a}}$ & $43.07 \pm 6.57^{\mathrm{a}}$ & $68.76 \pm 2.39^{\mathrm{b}}$ & $0.30 \pm 0.009^{\mathrm{a}}$ & $0.32 \pm 0.011^{\mathrm{a}}$ & $0.36 \pm 0.015^{\mathrm{b}}$ \\
\hline \multirow[t]{2}{*}{ Silt loam } & Upper soils & $52.04 \pm 3.78^{\mathrm{a}}$ & $46.65 \pm 4.12^{\mathrm{a}}$ & $64.93 \pm 5.64^{\mathrm{b}}$ & $0.35 \pm 0.007^{\mathrm{a}}$ & $0.36 \pm 0.005^{\mathrm{a}}$ & $0.41 \pm 0.015^{\mathrm{b}}$ \\
\hline & Lower soils & $52.04 \pm 3.78^{\mathrm{a}}$ & $47.13 \pm 8.04^{\mathrm{a}}$ & $67.58 \pm 8.47^{\mathrm{b}}$ & $0.35 \pm 0.007^{\mathrm{a}}$ & $0.37 \pm 0.010^{\mathrm{a}}$ & $0.39 \pm 0.002^{\mathrm{b}}$ \\
\hline \multirow[t]{2}{*}{ Sandy loam } & Upper soils & $75.96 \pm 3.78^{\mathrm{a}}$ & $73.54 \pm 3.17^{\mathrm{a}}$ & $87.70 \pm 1.26^{\mathrm{b}}$ & $0.39 \pm 0.010^{\mathrm{a}}$ & $0.39 \pm 0.010^{\mathrm{a}}$ & $0.45 \pm 0.019^{\mathrm{b}}$ \\
\hline & Lower soils & $75.96 \pm 3.78^{\mathrm{a}}$ & $65.25 \pm 8.42^{\mathrm{a}}$ & $87.66 \pm 1.62^{\mathrm{b}}$ & $0.39 \pm 0.010^{\mathrm{a}}$ & $0.40 \pm 0.010^{\mathrm{a}}$ & $0.43 \pm 0.014^{\mathrm{b}}$ \\
\hline
\end{tabular}

typical and reflects their feeding preference of surface grazing on decaying organic matter (Lavelle 1997). Although A. chlorotica is an endogeic earthworm and feeds by consuming soil, the earthworms still lost weight over the duration of the experiment except in the sandy loam (SaL) soil which has the highest organic matter content and therefore presumably more available food (Table 1).

\section{Impact of earthworms on \%WSA}

The addition of both earthworm species increased significantly the \%WSA of the upper and lower soils compared with the control. Our results agree with the majority of studies on earthworms and aggregation (Bossuyt et al. 2005; Buck et al. 2000; Edwards and Bohlen 1996; Flegel et al. 1998; Hamilton et al. 1988; Ketterings et al. 1997; Swaby 1950) that report an increase of \%WSA in the presence of earthworms, although in these studies, it is not always clear what depth of the soil was being inspected. Across the different soil types, L. terrestris increased \%WSA to $74 \pm 7 \%$ in the upper soil but only $67 \pm$ $7 \%$ in the lower soil compared with $53 \pm 9 \%$ in the controls, whereas for A. chlorotica there was no difference with depth with an average value of $74 \pm 11 \%$ WSA. Despite the restricted size of the mesocosms, this is consistent with the anecic earthworms' surface casting behaviour that will result in an accumulation of cast-derived aggregates in the surface layer compared with endogeics mixing soil and making extensive burrows filled with casts (Pérès et al. 1998; Whalen et al. 2015).

The SaL soil had the highest organic matter content of the three soils (Table 1) and the highest values of \%WSA (Table 2). This is consistent with previous studies that show that increased organic matter content of soils leads to better soil aggregation (Alagöz and Yilmaz 2009; Haynes 2005). Although the L soil has a higher content of clay-sized particles

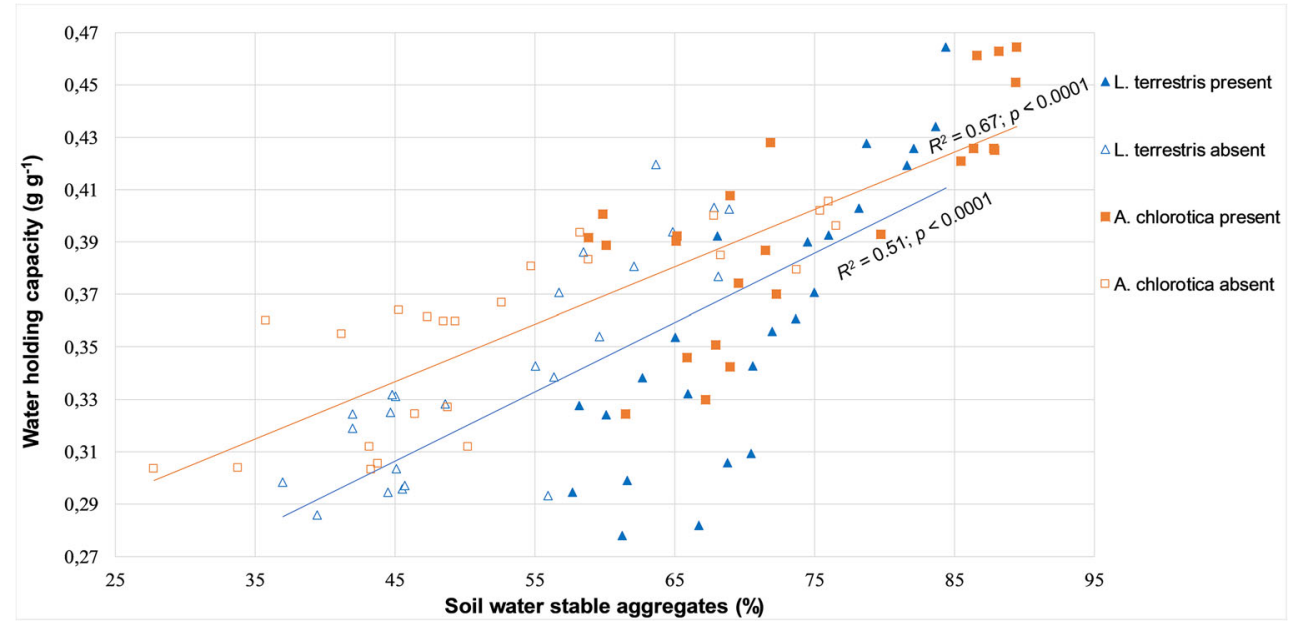

Fig. 1 Relationships between soil water stable aggregates and soil water holding capacity for all soil textures and for L. terrestris (blue symbols and correlation trend) and A. chlorotica (orange symbols and correlation trend). Filled and outline symbols indicate the presence and absence of earthworms, respectively. Lines of best fit to the data are $y=0.002648$
$(0.001882-0.003414) x+0.187(0.1388-0.2353)$ and $y=0.002189$ $(0.001736-0.002643) x+0.2381(0.2085-0.2678)$ for L. terrestris and A. chlorotica respectively with values in brackets indicating the $95 \%$ confidence intervals) 
than the other two soils and clay particles also play an important role in soil aggregation, these effects are less significant than those related to organic matter for clay contents of $<10 \%$ such as in the soils used in these experiments (Allison 1973). Although the SaL soil had the highest values of \%WSA, the largest relative increase in \%WSA was seen for the L soil, and the smallest increase in the SaL soil. This suggests that the contribution of earthworms to aggregation is more important in either or both lower \%OM or higher \%clay particle soils (Fig. 2). This could be because the contribution of earthworm mucus to organic binding agents (Knowles et al. 2016; Schomburg et al. 2018) or the stimulation of fungal activity via the increased supply of soluble organic compounds (Montecchio et al. 2015; Parle 1963; Rashid et al. 2016) is more significant in low-organic matter soils. Alternatively, or additionally, the earthworm activity may have a bigger impact on aggregate formation where there are more clay-sized particles available for aggregation. Interestingly, increased burrowing activity and cast production by endogeic earthworms as they process the soil for food has been observed in soils of lower organic $\mathrm{C}$ content which would lead to increased aggregate production (Bottinelli et al. 2017).

Although our results agree with the majority in the literature, several studies report what appear to be contrasting results, though differences in experimental design and measurement make comparisons and explanations of differences challenging. For example, Swaby (1950) found a bigger earthworm impact on \%WSA in organic-rich, pasture soil but considered earthworm casts of unknown age and produced by a different species, Allolobophora nocturna, rather than bulk soil. Milleret et al. (2009a) found a reduction in the \%WSA in the presence of A. chlorotica but conducted their experiment at a higher than optimum temperature for the earthworms (Butt 1991) which could have reduced the intensity of soil processing relative to our experiment and also have impacted on microbial activities involved in the formation and destruction of aggregates (e.g. Rashid et al. 2016; Shao et al.
2019). In addition, Milleret et al. (2009a) sterilized their soil with gamma irradiation, resulting in the removal of microbiota which may play an important synergistic role with earthworms in soil stabilization and aggregation (Forster 1990). In another experiment with similar conditions, Milleret et al. (2009b) found that the presence of plants partly compensate the decrease in soil aggregation that A. chlorotica caused and hypothesised that this was due to the aggregating effects of microorganisms that fed on the C-rich exudates released by plant roots. Zhang and Schrader (1993) and Schrader and Zhang (1997) reported a lower or the same \%WSA in earthworm casts obtained from the soil surface compared with the sieved soil that was initially used to make the substrate for their experiment. Our experimental measures are different from this as we compared the \%WSA in bulk soil that was either worked or not worked by earthworms. The experimental designs are very different making comparison difficult. It is possible that the pressure exerted by earthworms on the surrounding soil as they move contributes to the stability of the aggregates in the bulk soil regardless of the \%WSA of the casts and that the experimental design of Zhang and Schrader (1993) and Schrader and Zhang (1997) prevented this effect from being measured. In some studies (e.g. Blanchart et al. 1997) earthworms are added to intact soils which will have been in steady state with the previously existing earthworm population. As aggregate formation is a dynamic process with a constant production and destruction of aggregates, earthworms may be seen to reduce \%WSA if the $\%$ WSA in a soil is moving to a new steady state in response to the new earthworm community composition and abundance. Our experiments deliberately destroyed existing soil structure prior to the start of the experiment, which likely led to rapid soil aggregation. In a final example of apparently contrasting results, Shuster et al. (2000) observed a decrease in the mean size of WSA (of 5-8-, 2-5-, 1-2-, 0.5-1-, 0.25-0.5-, <0.25$\mathrm{mm}$ size classes) in soils following the addition of a mixture of immature and mature L. terrestris. However, we measured
Fig. 2 A conceptual model of the relationship between water stable aggregate formation and soil organic matter content in the presence and absence of earthworms. The dotted line is the difference between the earthworms absent and earthworms present lines and represents the enhanced formation of aggregates due to the presence of earthworms

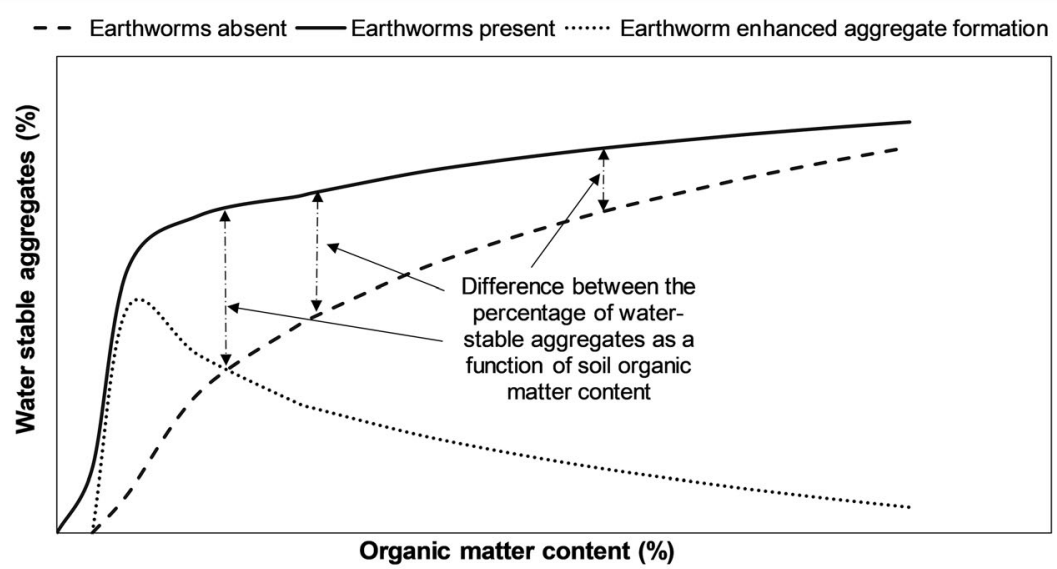


$\%$ WSA $>250 \mu \mathrm{m}$ by mass and not whether the size of these water stable aggregates was decreased. Although the mean aggregate size may decrease, the total mass of aggregates greater than $>250 \mu \mathrm{m}$, such as measured in our experiment, could still increase. These contrasted results are therefore most likely a function of experimental design and the actual measurements made.

\section{Impact of earthworms on WHC}

Various studies indicate that a higher \%WSA results in a higher WHC (Basche et al. 2016; Blanchart et al. 1999; Jackson 2014; Franzluebbers 2002; Suzuki et al. 2007; Zibilske and Bradford 2007). Similarly, in our work, linear regression of our \%WSA and WHC data (Fig. 1) showed a significant increase in the $\mathrm{WHC}$ as the \%WSA increases. The comparable slopes from the regressions of the A. chlorotica and $L$. terrestris data reflect a consistent relationship between increases in \%WSA and WHC regardless of earthworm species.

In contrast to the regression slopes, the significantly different intercepts of the regression lines for the A. chlorotica and $L$. terrestris data indicate a greater underlying impact on WHC by $A$. chlorotica than by $L$. terrestris separate from any $\%$ WSA effect. This could be due to the different burrowing behaviour of the earthworm species. A. chlorotica produces many tortuous small diameter burrows through the soil (Pérès et al. 1998) which help to hold more water whereas L. terrestris produces a smaller number of continuous and wider diameter pores (Capowiez et al. 2015). A simple approach for verifying this would be to perform infiltration measurements at different tensions and produce water release curves for different soils that both species have processed.

\section{Conclusion}

In these experiments, we have demonstrated that the increase in \%WSA due to earthworm-processing of soil results in increases in the important hydrological property WHC. Further, although the slope for the relationship between \%WSA and WHC is the same between the two different ecotypes of earthworms, the intercept is not; there was an underlying difference in the impact of the earthworms on WHC most likely due to the differing burrowing behaviours. In this experiment, we have used a high abundance of earthworms in a constrained volume of soil and not provided the earthworms with an additional food source to encourage soil processing in order to compensate for the 40-day period of the experiment compared with the far longer time that earthworms process soils in the field. Nonetheless, given the importance of \%WSA and WHC in ecosystem services such as water storage by soils and water availability to plants to support crop growth, our results are consistent with earthworms making an important contribution to these services. Despite the artificial nature of our experiments that constrain the extent to which the different earthworm species can behave, our experiments demonstrate that different ecotypes have different effects, due to their differing lifestyles and nature of the burrows, and that effects can differ with depth. This highlights that caution should be exercised when generalizing about the impacts that earthworms have on soil properties and processes. We also showed that the effects are a function of soil organic matter which also plays an important role in aggregation and water retention and which can have a more dominant effect than the earthworms.

To better understand the impact of earthworms on soil hydrology, further experiments are required that use a more realistic earthworm abundance and diversity. In addition, plant roots are known to have significant impacts on soil hydrology (Beven and Germann 1982; Whalley and Dexter 1994), and therefore, experiments that consider the relative impacts of plant roots and earthworms on soil hydrology are warranted.

Acknowledgements This research was supported by the Islamic Development Bank, National Institute of Agricultural Research of Morocco and the Environment and Geography Department, University of York, as part of Jamal Hallam's PhD work. We would like to acknowledge the help and support of Inma Lebron and David Robinson at CEH Bangor for help in accessing and using the WSA measurement equipment. We gratefully acknowledge helpful comments from the anonymous reviewers and the Editor in Chief, Paolo Nannipieri, that helped us to improve the manuscript.

Open Access This article is licensed under a Creative Commons Attribution 4.0 International License, which permits use, sharing, adaptation, distribution and reproduction in any medium or format, as long as you give appropriate credit to the original author(s) and the source, provide a link to the Creative Commons licence, and indicate if changes were made. The images or other third party material in this article are included in the article's Creative Commons licence, unless indicated otherwise in a credit line to the material. If material is not included in the article's Creative Commons licence and your intended use is not permitted by statutory regulation or exceeds the permitted use, you will need to obtain permission directly from the copyright holder. To view a copy of this licence, visit http://creativecommons.org/licenses/by/4.0/.

\section{References}

Abbott I, Parker CA (1981) Interactions between earthworms and their soil environment. Soil Biol Biochem 13:191-197. https://doi.org/ 10.1016/0038-0717(81)90019-5

Alagöz Z, Yilmaz E (2009) Effects of different sources of organic matter on soil aggregate formation and stability: a laboratory study on a Lithic Rhodoxeralf from Turkey. Soil Tillage Res 103:419-424. https://doi.org/10.1016/j.still.2008.12.006

Allison FE (1973) Chapter 16 A factor in soil aggregation and root development. In: Allison FE (ed) Developments in soil science. Elsevier, London, pp 315-345

Ayub M, Boyd CE (1994) Comparison of different methods for measuring organic carbon concentrations in pond bottom soils. J World 
Aquacult Soc 25:322-325. https://doi.org/10.1111/j.1749-7345. 1994.tb00198.x

Basche AD, Kaspar TC, Archontoulis SV, Jaynes DB, Sauer TJ, Parkin TB, Miguez FE (2016) Soil water improvements with the long-term use of a winter rye cover crop. Agric Water Manag 172:40-50. https://doi.org/10.1016/j.agwat.2016.04.006

Bastardie F, Capowiez Y, de Dreuzy JR, Cluzeau D (2003) X-ray tomographic and hydraulic characterization of burrowing by three earthworm species in repacked soil cores. Appl Soil Ecol 24:3-16. https://doi.org/10.1016/S0929-1393(03)00071-4

Berry EC, Jordan D (2001) Temperature and soil moisture content effects on the growth of Lumbricus terrestris (Oligochaeta: Lumbricidae) under laboratory conditions. Soil Biol Biochem 33:133-136 https:// doi.org/10.1016/S0038-0717(00)00112-7

Beven K, Germann P (1982) Macropores and water flow in soils. Water Resour Res 18:1311-1325.https://doi.org/10.1029/ WR018i005p01311

BIO Intelligence Service, Communities O for OP of the E (2014) Study on soil and water in a changing environment: final report. European Union (DG ENV), Luxembourg

Blanchart E (1992) Restoration by earthworms (megascolecidae) of the macroaggregate structure of a destructured savanna soil under field conditions. Soil Biol Biochem 24:1587-1594. https://doi.org/10. 1016/0038-0717(92)90155-Q

Blanchart E, Alegre J, Duboisset A, Lavelle P, Brussaard L (1999) Effects of earthworms on soil structure and physical properties. In: Lavelle P, Brussaard L, Hendrix P (eds) Earthworm management in tropical agroecosystems. CAB International, Wallingford, pp 149-171

Blanchart E, Lavelle P, Braudeau E, LeBissonnais Y, Valentin C (1997) Regulation of soil structure by geophagous earthworm activities in humid savannas of Cote d'Ivoire. Soil Biol Biochem 29:431-439. https://doi.org/10.1016/S0038-0717(96)00042-9

Blouin M, Hodson ME, Delgado EA, Baker G, Brussaard L, Butt KR, Dai J, Dendooven L, Peres G, Tondoh JE, Cluzeau D, Brun JJ (2013) A review of earthworm impact on soil function and ecosystem services. Eur J Soil Sci 64:161-182. https://doi.org/10.1111/ ejss. 12025

Blouin M, Lavelle P, Laffray D (2007) Drought stress in rice (Oryza sativa L.) is enhanced in the presence of the compacting earthworm Millsonia anomala. Environ Exp Bot 60:352-359. https://doi.org/ 10.1016/j.envexpbot.2006.12.017

Boivin P, Kohler-Milleret R (2011) Soil biota, impact on physical properties. In: Gliński J, Horabik J, Lipiec J (eds) Encyclopedia of agrophysics. Springer Netherlands, Dordrecht, pp 740-742

Bossuyt H, Six J, Hendrix PF (2006) Interactive effects of functionally different earthworm species on aggregation and incorporation and decomposition of newly added residue carbon. Geoderma 130:14 25. https://doi.org/10.1016/j.geoderma.2005.01.005

Bossuyt H, Six J, Hendrix PF (2005) Protection of soil carbon by microaggregates within earthworm casts. Soil Biol Biochem 37: 251-258. https://doi.org/10.1016/j.soilbio.2004.07.035

Bottinelli N, Jouquet P, Capowiez Y, Podwojewski P, Grimaldi M, Peng $\mathrm{X}$ (2015) Why is the influence of soil macrofauna on soil structure only considered by soil ecologists? Soil Tillage Res 146:118-124. https://doi.org/10.1016/j.still.2014.01.007

Bottinelli N, Zhou H, Capowiez Y, Zhang ZB, Qiu J, Jouquet P (2017) Earthworm burrowing activity of two non-Lumbricidae earthworm species incubated in soils with contrasting organic carbon content (Vertisol vs. Ultisol). Biol Fertil Soils 53:951-955. https://doi.org/ 10.1007/s00374-017-1235-8

Bouché MB (1977) Strategies lombriciennes. In: Lohm U, Persson T (eds) Soil organisms as components of ecosystems. Ecol. Bul, Stockholm, pp 122-133

Buck C, Langmaack M, Schrader S (2000) Influence of mulch and soil compaction on earthworm cast properties. Appl Soil Ecol 14:223229. https://doi.org/10.1016/S0929-1393(00)00054-8
Butt KR (1991) The effects of temperature on the intensive production of lumbricus-terrestris (Oligochaeta, Lumbricidae). Pedobiologia (Jena) 35:257-264

Butt KR, Lowe CN (2011) Controlled cultivation of endogeic and anecic earthworms. In: Karaca A (ed) Biology of earthworms. Springer, Berlin Heidelberg, pp 107-121

Capowiez Y, Bottinelli N, Sammartino S, Michel E, Jouquet P (2015) Morphological and functional characterisation of the burrow systems of six earthworm species (Lumbricidae). Biol Fertil Soils 51: 869-877. https://doi.org/10.1007/s00374-015-1036-X

Capowiez Y, Sammartino S, Michel E (2014) Burrow systems of endogeic earthworms: effects of earthworm abundance and consequences for soil water infiltration. Pedobiologia (Jena) 57:303-309. https://doi.org/10.1016/j.pedobi.2014.04.001

CEAE (2003) Determination de la matiere organique par incineration: Methode de perte de feu (PAF). Centre d'expertise en analyse environnementale du Québec, Quebec

Cohen J (1988) In: 2nd (ed) Statistical power analysis for the behavioral sciences. L. Erlbaum Associates, Hillsdale

Cornforth IS (1968) The effect of the size of soil aggregates on nutrient supply. J Agric Sci 70:83-85. https://doi.org/10.1017/ S0021859600017238

Edwards CA (2004) Earthworm ecology, 2nd edn. CRC Press, Boca Raton

Edwards CA, Bohlen PJ (1996) Biology and Ecology of Earthworms, 3rd edn. Chapman and Hall, London, UK, pp 426

Ernst G, Felten D, Vohland M, Emmerling C (2009) Impact of ecologically different earthworm species on soil water characteristics. Eur J Soil Biol 45:207-213. https://doi.org/10.1016/j.ejsobi.2009.01.001

Field A (2009) Discovering statistics using SPSS. SAGE Publications Ltd, London

Flegel M, Schrader S, Zhang H (1998) Influence of food quality on the physical and chemical properties of detritivorous earthworm casts. Appl Soil Ecol 9:263-269. https://doi.org/10.1016/S0929-1393(97) 00050-4

Forster SM (1990) The role of microorganisms in aggregate formation and soil stabilization: types of aggregation. Arid Soil Res Rehabil 4: 85-98. https://doi.org/10.1080/15324989009381236

Franzluebbers AJ (2002) Water infiltration and soil structure related to organic matter and its stratification with depth. Soil Tillage Res 66: 197-205 https://doi.org/10.1016/S0167-1987(02)00027-2

Frund HC, Butt K, Capowiez Y, Eisenhauer N, Emmerling C, Ernst G, Potthoff M, Schadler M, Schrader S (2010) Using earthworms as model organisms in the laboratory: recommendations for experimental implementations. Pedobiologia (Jena) 53:119-125. https:// doi.org/10.1016/j.pedobi.2009.07.002

Guber A, Pachepsky YA, Shein E, Rawls WJ (2004) Soil aggregates and water retention. In: Pachepsky Y, Rawls WJ (eds) Development of Pedotransfer Functions in Soil Hydrology. Elsevier, Amsterdam, pp 143-151

Guild WJM (1955) Earthworms and soil structure. In: Kevan DKM (ed) Soil zoology. Butterworths, London, pp 83-98

Hallam J, Berdeni D, Grayson R, Guest EJ, Holden J, Lappage MG, Prendergast-Miller MT, Robinson DA, Turner A, Leake JR, Hodson ME (2020) Effect of earthworms on soil physicohydraulic and chemical properties, herbage production, and wheat growth on arable land converted to ley. Sci Total Environ 713: 136491. https://doi.org/10.1016/j.scitotenv.2019.136491

Hamilton WE, Dindal DL, Parkinson CM, Mitchell MJ (1988) Interaction of earthworm species in sewage sludge-amended soil microcosms: Lumbricus terrestris and Eisenia fetida. J Appl Ecol 25:847-852. https://doi.org/10.2307/2403750

Haynes RJ (2005) Labile organic matter fractions as central components of the quality of agricultural soils: an overview. In: Sparks DL (ed) Advances in agronomy. Academic Press, London, pp 221-268 
Haynes RJ, Fraser PM (1998) A comparison of aggregate stability and biological activity in earthworm casts and uningested soil as affected by amendment with wheat or lucerne straw. Eur J Soil Sci 49:629636

Holden J, Grayson RP, Berdeni D, Bird S, Chapman PJ, Edmondson JL, Firbank LG, Helgason T, Hodson ME, Hunt SFP, Jones DT, Lappage MG, Marshall-Harries E, Nelson M, Prendergast-Miller M, Shaw H, Wade RN, Leake JR (2019) The role of hedgerows in soil functioning within agricultural landscapes. Agric Ecosyst Environ 273:1-12. https://doi.org/10.1016/j.agee.2018.11.027

Hong SY, Minasny B, Han KH, Kim Y, Lee K (2013) Predicting and mapping soil available water capacity in Korea. PeerJ 1:e71. https:// doi.org/10.7717/peerj.71

Hopp H, Hopkins HT (1946) Earthworms as a factor in the formation of water-stable aggregates. J Soil Water Conserv 1:11-13

Hudson BD (1994) Soil organic-matter and available water capacity. J Soil Water Conserv 49:189-194

International Organization for Standardization (2019) Soil qualitydetermination of water retention characteristics-Laboratory methods,No. 11274. Geneve

Jackson RS (2014) 5-site selection and climate. In: Wine Science, Fourth edn. Academic Press, San Diego, pp 307-346

Jégou D, Schrader S, Diestel H, Cluzeau D (2001) Morphological, physical and biochemical characteristics of burrow walls formed by earthworms. Appl Soil Ecol 17:165-174. https://doi.org/10.1016/ S0929-1393(00)00136-0

Jones DT, Lower CN (2009) Key to Common British Earthworms. Field Studies Council, Shrewsbury, UK

Ketterings QM, Blair JM, Marinissen JCY (1997) Effects of earthworms on soil aggregate stability and carbon and nitrogen storage in a legume cover crop agroecosystem. Soil Biol Biochem 29:401408. https://doi.org/10.1016/S0038-0717(96)00102-2

Knowles ME, Ross DS, Görres JH (2016) Effect of the endogeic earthworm Aporrectodea tuberculata on aggregation and carbon redistribution in uninvaded forest soil columns. Soil Biol Biochem 100: 192-200. https://doi.org/10.1016/j.soilbio.2016.06.016

Kodešová R, Vignozzi N, Rohošková M, Hájková T, Kočárek M, Pagliai M, Kozák J, Šimůnek J (2009) Impact of varying soil structure on transport processes in different diagnostic horizons of three soil types. J Contam Hydrol 104:107-125. https://doi.org/10.1016/j. jconhyd.2008.10.008

Lavelle P (1997) Faunal activities and soil processes: adaptive strategies that determine ecosystem function. Adv Ecol Res 27(27):93-132. https://doi.org/10.1016/S0065-2504(08)60007-0

Lavelle P, Blanchart E, Martin A, Spain AV, Martin S (1992) Impact of soil fauna on the properties of soils in the humid tropics. Soil Science Society of America, Madison

Lee KE, Foster RC (1991) Soil fauna and soil structure. Aust J Soil Res 29:745-775. https://doi.org/10.1071/SR9910745

Li X, Zhang Q, Ye X (2013) Effects of spatial information of soil physical properties on hydrological modeling based on a distributed hydrological model. Chin Geogr Sci 23:182-193. https://doi.org/10.1007/ s11769-013-0599-4

Lowe CN, Butt KR (2005) Culture techniques for soil dwelling earthworms: a review. Pedobiologia (Jena) 49:401-413. https://doi.org/ 10.1016/j.pedobi.2005.04.005

Milleret R, Le Bayon R-C, Gobat J-M (2009a) Root, mycorrhiza and earthworm interactions: their effects on soil structuring processes, plant and soil nutrient concentration and plant biomass. Plant Soil 316:1-12. https://doi.org/10.1007/s11104-008-9753-7

Milleret R, Le Bayon RC, Lamy F, Gobat JM, Boivin P (2009b) Impact of roots, mycorrhizas and earthworms on soil physical properties as assessed by shrinkage analysis. J Hydrol 373:499-507. https://doi. org/10.1016/j.jhydrol.2009.05.013

Ministry of Agriculture Fisheries and Food (1986) The analysis of agricultural materials. H.M.S.O, London
Montecchio L, Scattolin L, Squartini A, Butt KR (2015) Potential spread of forest soil-borne fungi through earthworm consumption and casting. Iforest-Biogeosciences For 8:295-301. https://doi.org/10.3832/ ifor1217-008

Palm J, van Schaik NLMB, Schroder B (2013) Modelling distribution patterns of anecic, epigeic and endogeic earthworms at catchmentscale in agro-ecosystems. Pedobiologia (Jena) 56:23-31. https://doi. org/10.1016/j.pedobi.2012.08.007

Parle JN (1963) A microbiological study of earthworm casts. J Gen Microbiol 31:13-22. https://doi.org/10.1099/00221287-31-1-13

Pérès G, Cluzeau D, Curmi P, Hallaire V (1998) Earthworm activity and soil structure changes due to organic enrichments in vineyard systems. Biol Fertil Soils 27:417-424. https://doi.org/10.1007/ s003740050452

Ramachandran Nair PK, Nair VD, Mohan Kumar B, Showalter JM (2010) Chapter five-carbon sequestration in agroforestry systems. In: Sparks DL (ed) Advances in agronomy. Academic Press, Amsterdam, pp 237-307

Rashid MI, Mujawar LH, Shahzad T, Almeelbi T, Ismail IM, Oves M (2016) Bacteria and fungi can contribute to nutrients bioavailability and aggregate formation in degraded soils. Microbiol Res 183:2641. https://doi.org/10.1016/j.micres.2015.11.007

Rousseva S, Kercheva M, Shishkov T, Lair GJ, Nikolaidis NP, Moraetis D, Krám P, Bernasconi SM, Blum WEH, Menon M, Banwart SA (2017) Chapter two-soil water characteristics of European SoilTrEC critical zone observatories. In: Banwart SA, Sparks DL (eds) Advances in agronomy. Academic Press, San Diego, pp 29-72

Saha D, Kukal SS (2015) Soil structural stability and water retention characteristics under different land uses of degraded lower Himalayas of North-West India. L Degrad Dev 26:263-271. https://doi.org/10.1002/ldr.2204

Saxton KE, Rawls WJ, Romberger JS, Papendick RI (1986) Estimating generalized soil-water characteristics from texture. Soil Sci Soc Am J 50:1031-1036

Schneider AK, Schroder B (2012) Perspectives in modelling earthworm dynamics and their feedbacks with abiotic soil properties. Appl Soil Ecol 58:29-36. https://doi.org/10.1016/j.apsoil.2012.02.020

Schomburg A, Verrecchia EP, Guenat C, Brunner P, Sebag D, Le Bayon RC (2018) Rock-Eval pyrolysis discriminates soil macro-aggregates formed by plants and earthworms. Soil Biol Biochem 117:117-124 . https://doi.org/10.1016/j.soilbio.2017.11.010

Schrader S, Zhang H (1997) Earthworm casting: stabilization or destabilization of soil structure? Soil Biol Biochem 29:469-475. https://doi. org/10.1016/S0038-0717(96)00103-4

Shao Y, Zhang W, Eisenhauer N, Liu T, Ferlian O, Wang X, Xiong Y, Liang C, Fu S (2019) Exotic earthworms maintain soil biodiversity by altering bottom-up effects of plants on the composition of soil microbial groups and nematode communities. Biol Fertil Soils 55: 213-227. https://doi.org/10.1007/s00374-019-01343-0

Shipitalo MJ, Le Bayon R-C (2004) Quantifying the effects of earthworms on soil aggregation and porosity. In: Edwards CA (ed) Earthworm ecology. CRC Press, Bosa Roca, pp 183-200

Shipitalo MJ, Protz R (1989) Chemistry and micromorphology of aggregation in earthworm casts. Geoderma 45:357-374. https://doi.org/ 10.1016/0016-7061(89)90016-5

Shuster WD, Subler S, McCoy EL (2000) Foraging by deep-burrowing earthworms degrades surface soil structure of a fluventic Hapludoll in Ohio. Soil Tillage Res 54:179-189

Six J, Feller C, Denef K, Ogle SM, Sa JCM, Albrecht A (2002) Soil organic matter, biota and aggregation in temperate and tropical soils-effects of no-tillage. Agronomie 22:755-775

Smagin AV, Prusak AV (2008) The effect of earthworm coprolites on the soil water retention curve. Eurasian Soil Sci 41:618-622. https://doi. org/10.1134/S1064229308060069

Snyder BA, Boots B, Hendrix PF (2009) Competition between invasive earthworms (Amynthas corticis, Megascolecidae) and native North 
American millipedes (Pseudopolydesmus erasus, Polydesmidae): effects on carbon cycling and soil structure. Soil Biol Biochem 41: 1442-1449. https://doi.org/10.1016/j.soilbio.2009.03.023

Stockdill SMJ, Cossens GG (1969) Earthworms a must for maximum production. New Zeal J Agric 119:61-67

Suzuki S, Noble AD, Ruaysoongnern S, Chinabut N (2007) Improvement in water-holding capacity and structural stability of a sandy soil in Northeast Thailand. Arid L Res Manag 21:37-49. https://doi.org/10.1080/15324980601087430

Swaby RJ (1950) The influence of earthworms on soil aggregation. J Soil Sci 1:195-196. https://doi.org/10.1111/j.1365-2389.1950.tb00730.x

Whalen JK, Han L, Dutilleul P (2015) Burrow refilling behavior of Aporrectodea turgida (Eisen) and Lumbricus terrestris L. as revealed by X-ray computed tomography scanning: graphical and quantitative analyses. Can J Soil Sci 95:231-235. https://doi.org/10.4141/ cjss-2014-040

Whalley WR, Dexter AR (1994) Root development and earthworm movement in relation to soil strength and structure. Arch Agron Soil Sci 38:1-40. https://doi.org/10.1080/03650349409365834
WRB (2006) World reference base for soil resources, 2nd edn. ISRICFAO, Rome

Zhang H, Schrader S (1993) Earthworm effects on selected physical and chemical properties of soil aggregates. Biol Fertil Soils 15:229-234. https://doi.org/10.1007/bf00361617

Zhang Y, Zhang M, Niu J, Li H, Xiao R, Zheng H, Bech J (2016) Rock fragments and soil hydrological processes: significance and progress. Catena 147:153-166. https://doi.org/10.1016/j.catena.2016.07. 012

Zibilske LM, Bradford JM (2007) Soil aggregation, aggregate carbon and nitrogen, and moisture retention induced by conservation tillage. Soil Sci Soc Am J 71:793-802. https://doi.org/10.2136/sssaj2006. 0217

Publisher's note Springer Nature remains neutral with regard to jurisdictional claims in published maps and institutional affiliations. 